\title{
Yield Performance of Sesame (Sesamum indicum L.) Varieties at Different Levels of Plant Population in Optimum Moisture Areas of Western Tigray, Northern Ethiopia
}

\author{
Weres Negash Golla \\ Department of Crop, Humera Agricultural Research Center, P.O. Box 62 Humera, Ethiopia
}

\begin{abstract}
The production of sesame (Sesame indicum L.), an important oil crop produced for export in Ethiopia, is affected by environmental and biotic factors as well as management practices. Determining the optimum plant population in optimum moisture areas for sesame is crucial to boost sesame productivity. A field experiment was conducted at Zuria-Dansha, in optimum moisture areas of western Tigray to evaluate yield performance of sesame varieties at different levels of plant population. The experiment was laid out in RCBD in factorial arrangement with three varieties of sesame (Gida-Ayana, Humera-1 and Hirhr) and four plant population (80,000, $124,444,250,000$ and 666,666 plants/ha) in three replications. The result revealed that varieties and plant population significantly differed in yield and yield related traits. The variety Gida-Ayana recorded maximum fertile capsules per plant, thousand seed weight, seed per capsule and oil content (\%) while the local variety Hirhr recorded the least. The yield components like: fertile capsules per plant, seed per capsule and thousand seed weight were highest in the low plant population than highest plant population but oil content (\%) was not affected by different levels of plant population. The highest seed yield was obtained from variety Gida-Ayana grown at 250,000 plants $(10 \mathrm{~cm} \times 40 \mathrm{~cm})$ which significantly increases yield by $34.75 \%$ as compared with local variety Hirhr with the same plant population. Hence, it can be concluded that higher seed yield and oil content (\%) of sesame could be obtained by using Gida-Ayana variety sowing at the plant population of 250,000 plants $/ \mathrm{ha}(40 \mathrm{~cm} \times 10 \mathrm{~cm})$ under optimum moisture areas of western Tigray and similar agro-climatic conditions. Keywords: Optimum moisture, performance, plant population, Sesame, Varieties, Yield
\end{abstract}

DOI: $10.7176 / \mathrm{JBAH} / 10-4-03$

Publication date: February $29^{\text {th }} 2020$

\section{Introduction}

Sesame (Sesamum indicum L.) otherwise known as sesamum, member of the family Pedaliaceae, is one of the ancient oilseed domesticated and cultivated in tropical and sub-tropical parts of the world by man for the edible oil and medicinal purposes for more than 5000 years (Khan et al., 2009 and Umar et al., 2010). Though it is a controversy for the origin of sesame, it is believed to be originated in Ethiopia due to existence of both cultivated and wild types in the country (Wijnands et al., 2009). Ethiopia is one of the popular sesame producers in the world and the seed produced in western Tigray (Humera type) is highly competent in the world market by its desirable qualities in terms of color, taste and aroma (Taghouti et al., 2017). Sesame is used one of the main cash crops and the second export commodity, next to coffee in Ethiopia and plays significant role as source of rural employment and ensuring food-security of millions of people (Abebe, 2016).

The crop is grown under different environments which may affect its growth performance. Environmental and biotic factors (weed, disease and insect pest) as well as management practices are the main sesame production constraints. The environmental factors include temperature, rain fall and soil types. Areas with annual rainfall of $625-1100 \mathrm{~mm}$, deep, well-drained, fertile sandy loams and temperature of $>27^{\circ} \mathrm{c}$ is the most conducive for sesame production (Geremew et al., 2012). The management practice on the other hand includes plant population, time of sowing, type and rate of fertilizers. The plant population per unit area plays a vital role in determining the final seed yield of crops (Malik et al., 2003) and types of sesame varieties that adapt for that particular area may also be critical to boost sesame production.

The productivity of sesame $(607 \mathrm{~kg} / \mathrm{ha})$ in Tigray region is lower than the national average yield of 686 $\mathrm{kg} / \mathrm{ha}$ (CSA, 2019) while in the optimum moisture areas of Western Tigray (specifically in the study area) is about $3.5 \mathrm{~kg} / \mathrm{ha}-4.5 \mathrm{~kg} / \mathrm{ha}$ (personal communication with bureau of agriculture/BOA). However, sesame productivity can go up to $1000-1200 \mathrm{~kg} / \mathrm{ha}$ under optimum agronomic cultivation (Ali et al., 1997). The low productivity of sesame in the study area might be due to cultivation of low yielding varieties and poor management practices like inappropriate plant density. Plant population is one of the agronomic management practices and manipulation of that could increase yield performances of sesame varieties. The effect of plant population on yield and yield components of sesame have been reported by several researchers. Kale et al., 2018 and Roy et al., 2009 reported that, inter and intra row spacing of $30 \mathrm{~cm}$ x $10 \mathrm{~cm}$ was obtained higher seed yield and yield components in sesame. However, the effect of sesame varieties planted in different plant population in optimum moisture areas of western Tigray is not yet conducted so that identification of optimum population and 
sesame varieties in the study area becomes relevant. Therefore, this study was conducted to determine the yield performance of three sesame varieties at different plant population to develop plant population recommendations for sesame production in optimum moisture areas of western Tigray, northern Ethiopia.

\section{Materials and Methods}

The experiment was conducted during 2018 cropping season in the optimum moisture areas of western Tigray at "Zuria-Dansha". The site is located at geographical coordinates of 13o 38' 306" North latitude and 36o 52' 84.1" East longitude and altitude of $747 \mathrm{~m}$.a.s.l. According to meteorological agency record the area receives mean annual rainfall and temperature of $888.4 \mathrm{~mm}$ and $28.7{ }^{\circ} \mathrm{C}$, respectively. The experiment consisted of two released sesame varieties (Gida-Ayana, and Setit-2) and one local Hirhr and four plant population. To achieve the required planting density per ha, the intra and inter row spacing were placed in brackets, respectively. The plant populations were 80,000 plants/ha $(20 \mathrm{~cm} \times 60 \mathrm{~cm}), 124,444$ plants/ha $(15 \mathrm{~cm} \times 50 \mathrm{~cm}), 250,000$ plants/ha $(10 \mathrm{~cm} \times 40 \mathrm{~cm})$ and 666,666 plants/ha $(5 \mathrm{~cm} \times 30 \mathrm{~cm}$ and there were $6,7,9$ and 12 rows in each plot, respectively. The experiment was laid out in Randomized Complete Block Design (RCBD) with three replications where each plot size was $9 \mathrm{~m}^{2}$ (3.6 m width by $2.5 \mathrm{~m}$ length) having between plots and blocks distance of $1 \mathrm{~m}$ and $1.5 \mathrm{~m}$, respectively. Seeds were manual drilled in rows and urea fertilizer $(50 \mathrm{~kg} / \mathrm{ha}) \mathrm{was}$ applied in split applications (half at sowing and half before flowering) while DAP (100 kg/ha) fertilizer was applied only at sowing time. All plots were weeded as per the recommendation. When the plants attained height of 10 to $15 \mathrm{~cm}$, seedlings were thinned out to the specified distance between plants to obtain the required plant population. Harvested plants from each plot were separately kept in sacks for drying for two weeks and threshed manually. All other agronomic practices were kept normal and uniform for all treatments.

2.1. Data collected. The following agronomic data were recorded from the central rows of each treatment.

(i) Number of fertile capsules per plant (NFCPP): The mean numbers of capsules obtained from 10 pre-tagged plants at harvest.

(ii) Number of seed per capsule (NSPC): The mean numbers of seeds per capsule were obtained from 10 randomly taken plants at harvest by taking three capsules per plant.

(iii) Thousand seed weight (TSW): weight in grams of 1000 randomly chosen seeds. Seed yield (kg/ha):

(iv) Seed yield $(\mathrm{kg} / \mathrm{ha})$ : the total seed yield $(\mathrm{kg} / \mathrm{ha})$ harvested from the net plot area

(v) Oil content (\%): Determined from 40 gram samples taken from each treatment using Nuclear Magnetic Resonance

2.2. Data analysis. The recorded date were analyzed using statistical software of GenStat-18 for the analysis of variance and Duncan's Multiple Range Test (DMRT) was used to separate differences among treatment means at $5 \%$ and $1 \%$ probability level.

\section{Results and Discussions}

3.1. Variance Estimation of Yield and Yield Related Traits. The results of yield and yield related traits obtained from the analysis of variance (ANOVA) of the sesame varieties and plant population are described in Table 1 . The variety, plant population, and variety by plant population interaction variances were decomposed to provide a general overview in relation to the yield and yield related traits of sesame varieties planted with different plant population. As a result, variety $\times$ plant population interaction showed statistically significant variation $(p<0.05)$ for seed yield. However, only the main effect of variety and plant population were statistically highly significant $(\mathrm{p}<0.001)$ for the traits: number of fertile capsule per plant NFCPP), number of seeds per capsule (NSPC) and thousand seed weight (TSW). The described statistical difference was due to both the main and interaction effect of sesame varieties and plant population. As indicated in Table 3 below, the varieties and plant population were clearly different (highly significant for both main effects) in their yield and yield related traits, in which the experiment was conducted. This might be due to the variations of adoptability of the varieties to the soil and climatic conditions of the experimental area and differences in nutrient utilization of the different plant population in optimum moisture areas. 
Table 1: Mean squares values for different agronomic traits of sesame varieties planted with different plant population

\begin{tabular}{|l|l|l|l|l|l|}
\hline Source of Variation & DF & Seed Yield (kg/ha) & NFCPP & NSPC & TSW (g) \\
\hline Replication & 2 & 3105 & 7.41 & 62.66 & 0.17361 \\
\hline Varity & 2 & $70730^{* *}$ & $813.22^{* *}$ & $1887.65^{* *}$ & $0.337^{* *}$ \\
\hline Plant population & 3 & $28128^{* *}$ & $546.45^{* *}$ & $363.77^{* *}$ & $0.344^{* *}$ \\
\hline Varity $\times$ Plant population & 6 & $5186^{*}$ & $20.49 \mathrm{~ns}$ & $23.13 \mathrm{~ns}$ & $0.065 \mathrm{~ns}$ \\
\hline Residual & 22 & 1761 & 23.61 & 46.98 & 0.039 \\
\hline
\end{tabular}

DF: degree of freedom; NFCPP: number of fertile capsules per plant; NSPC: number of seeds per capsule; TSW $(\mathrm{g})$ : thousand seed weight in gram; ns: non-significant $(\mathrm{p}<0.05) ;{ }^{*}$ significant at $\mathrm{p}<0.05 ;{ }^{* *}$ highly significant at $\mathrm{p}<0.01$.

3.2. Number of Fertile capsules per plant. The analysis of variance indicated that highly significant differences $(p<0.01)$ were found among the main effects of sesame varieties and plant population, their interaction for number of capsules per plant was not statistically significant (Table 1). The highest number of capsules per plant (44.17) was obtained for variety Gida-Ayana planted while the variety Hirhr gave the lowest number of capsules per plant (27.89) as indicated in Table 2. The maximum number of capsules per plant obtained might be attributed to the genetic difference of the varieties and the suitable agro-climatic conditions for the new variety Gida-Ayana. As described by Valiki et al. (2015), significant differences were found among sesame varieties in the number of capsules per plant due to the genetic difference of the varieties. The result is also corroborated with Begum et al. (2001) who reported that, there is a variation in number of capsules per plant evaluated for different sesame varieties due to the existence of suitable climatic conditions for the varieties in the tested area.

The effect of plant population on number of capsules per plant on the other hand showed that, the highest (44.07) was recorded from sesame grown at the lowest plant population while the lowest (26.01) was recorded from sesame grown at the highest plant population. The increment in the number of capsules per plant as the number of plants per unit area decreases shows the importance of plant population in determining the number of capsules per plant; it may be due to optimum air movement and low competition for nutrients. This finding is in line with Mohhamed and Hamidu, 2018 who reported that effect of spacing was significant; 20x70 $\mathrm{cm}$ spacing had the maximum number of capsule whereas $20 \times 40 \mathrm{~cm}$ spacing had minimum number of capsule. It was also reported that lower plant density increases number of capsules per plant in sesame Ahmed et al. (2002).

3.3. Number of seeds per capsule. The main effect of variety and plant population showed highly significant $(p<0.01)$ effect on number of seed per capsule while the interaction effect of variety and plant population was non-significant (Table 1). From among the varieties, the highest number of seed per capsule (72.58) was obtained from the variety Gida-Ayana and the lowest from variety Hirhr (48.25) (Table 2). This could be due to the inherent genetic variation existing in the varieties. Both Kathiresan (2002) and Begum et al. (2001) reported similar findings, sesame varieties differed on number of seeds per capsule. A research done by Gabisa et al. (2015) also found that groundnut varieties varies in number of seeds per pod and the authors explained that number of seed per pod is mainly influenced by genetic factors found in the different varieties than agronomic practices.

The highest number of seed per capsule was recorded at the planting density of 80,000 plants/ha. On the contrary, the lowest number of seed per capsule was recorded at planting density of 666,666 plants ha-1 (Table 1). This could be due to the increase in plant density and increased intra specific competition, which eventually caused reduction in the number of seeds per capsule in the highest plant population. These findings corroborated with the report of Caliskan et al. (2004) who found that the maximum number of seeds per capsule was recorded from lowest plant population (102,000 plants/ha) while lower value of seeds per capsule was recorded from highest plant population (512,000 plants/ha). Similarly Roy et al., 2009 reported that with the increase of row spacing number of seeds per capsule increased. In contrary, number of seeds per panicle was not affected by change in plant density Kale et al. (2018).

3.4. Thousand Seed Weight (g). The analysis of variance revealed that the main effect of variety and planting density on thousand seed weight of sesame was highly significant $(p<0.01)$ but not the interaction (Table 1). The highest thousand seed weight (2.3g) was observed for variety Setit-2 which is at par with variety Gida-Ayana which had thousand seed weight of $2.2 \mathrm{~g}$ and the lowest 1000 seed weight was recorded for variety Hirhr $(1.97 \mathrm{~g})$ (Table 2). The reason might be due to the genetic makeup of the variety as described by Govindarasou et al. (1998). This result is in agreement with Sivangamy and Rammohan (2013) found that 1000-seed weight was affected by sesame varieties.

The planting density of 80,000 plants ha/ha recorded the highest thousand seed weight $(2.3 \mathrm{~g})$ which is at par with planting density of 124,444 plants/ha whereas the lowest thousand seed weight was obtained from planting 
density of 666,666 plants/ha followed by planting density of 250,000 plants/ha (Table 2). At lower planting density, there would be improved accumulation of food ingredients in the seed due to the optimum availability of nutrients and water, optimum air movement in the plant micro-climate; this helps the weight of 1000-seeds to be increased. This result is in agreement with that of Lakew et al. (2018) who reported that thousand seed weight decreased as plant population per unit area increased. The inter-row spacing of $40 \mathrm{~cm}$ and $3.5 \mathrm{~kg}$ seeding rate recorded highest seed weight $(3.56 \mathrm{~g})$ than with same row spacing and $6.5 \mathrm{~kg}$ seeding rate $(3.06 \mathrm{~g})$ in sesame. Significant difference was also observed in plant density effect on hundred seed weight of haricot bean by Abate (2003). Hundred seed weight was decreased with increase plant density. On the other hand, non-significant difference was also reported in different sesame plant population for 1000-seed weight by Valiki et al. (2015) and Ahmad et al. (2002).

3.5. Oil Content $(\%)$. The main effect of variety exerts highly significant $(p<0.01)$ effect on oil content of sesame. However, there is no significant difference in planting density and interaction effect on oil content of sesame varieties planted with different plant population (Table 1). The genetic difference of the varieties may provide different seed oil content percentage. The variety Gida-Ayana recorded higher seed oil content (52.74\%) while the lower seed oil content of $46.99 \%$ was recorded in the variety Hirhr (Table 2). Seed oil content of sesame varieties were not affected significantly by the various planting densities under study. However, increasing planting density decreases seed oil percentage. May be the lower number of plants per unit area helps the growth of plants that are good for the availability of nutrients, air movement, decrease disease development, thereby increasing the accumulation of food ingredients in seeds as part of oil content of seeds. Similar findings were reported by Valiki et al., 2015, sesame cultivar had significant effect on oil percentage while plant density had no effect on oil percentage and the authors reported that although plant density did not affect oil percentage of sesame cultivars, but as plant density increases oil percentage of the cultivars decrease. According to Rahnama and Bakhshandeh (2006), seed oil percentage increases as plant distance increase up to $60 \mathrm{~cm}$.

Table 2: Effect of planting density on number of capsules per plant (NFCPP), thousand seed weight (TSW), number of seed per capsule (NSPC) and oil content (\%) of sesame at Kebabo during 2018 cropping season

\begin{tabular}{lllll}
\hline Variety & NFCPP & TSW $(\mathrm{g})$ & NSPC & Oil content (\%) \\
\hline Gida-Ayana & $44.17^{\mathrm{a}}$ & $2.3^{\mathrm{a}}$ & $72.9^{\mathrm{a}}$ & $52.8^{\mathrm{a}}$ \\
Humera-1 & $33.97^{\mathrm{b}}$ & $2.1^{\mathrm{ab}}$ & $61.3^{\mathrm{ab}}$ & $47.2^{\mathrm{c}}$ \\
Hirhr & $27.89^{\mathrm{c}}$ & $1.8^{\mathrm{b}}$ & $47.3^{\mathrm{b}}$ & $46.8^{\mathrm{c}}$ \\
\hline LSD $(<5 \%)$ & 4.11 & 0.17 & 8.80 & 0.80 \\
\hline Plant population & & & & \\
\hline 80,000 plants/ha & $44.07^{\mathrm{a}}$ & $2.33^{\mathrm{a}}$ & $58.53^{\mathrm{a}}$ & $47.02^{\mathrm{a}}$ \\
124,444 plants/ha & $38.69^{\mathrm{b}}$ & $2.00^{\mathrm{ab}}$ & $47.30^{\mathrm{b}}$ & $47.3^{\mathrm{a}}$ \\
250,000 plants/ha & $32.56^{\mathrm{c}}$ & $1.80^{\mathrm{b}}$ & $46.00^{\mathrm{b}}$ & $46.83^{\mathrm{a}}$ \\
666,666 plants/ha & $26.01^{\mathrm{d}}$ & $1.77^{\mathrm{b}}$ & $41.2^{\mathrm{b}}$ & $46.80^{\mathrm{a}}$ \\
\hline LSD (<5\%) & 4.75 & 0.19 & 6.70 & 0.9 \\
\hline CV\% & 13.8 & 9.3 & 11.0 & 1.9 \\
\hline
\end{tabular}

LSD: Least significance difference; CV (\%): Coefficient of variation; Means of the same letters are not significantly different at $5 \%$ level of significance.

3.6. Seed Yield $(\mathbf{k g} / \mathbf{h a})$. The analysis of variance showed that highly significant difference $(\mathrm{p}<0.01)$ were found for the main effects of varieties and plant population whereas, the interaction effect of variety and plant population on seed yield $(\mathrm{kg} / \mathrm{ha})$ was significant $(\mathrm{p}<0.05)$ (Table 1$)$. The highest seed yield $(656.7 \mathrm{~kg} / \mathrm{ha}) \mathrm{was}$ obtained for variety Gida-Ayana with 250,000 plants/ha $(10 \mathrm{~cm} \times 40 \mathrm{~cm})$ while the lowest seed yield $(383.7$ $\mathrm{kg} / \mathrm{ha}$ ) was obtained for variety Hirhr with 80,000 plants $/$ ha $(20 \mathrm{~cm} \times 80 \mathrm{~cm})($ Table 3$)$. The higher seed yield in variety Gida-Ayana with 250,000 plants/ha might be attributed to higher yield potential of the variety and efficient use of resources in the 250,000 plants/ha and the variety might be adapted to the climate and edaphic factors of the tested area. Since the variety was released from areas of high rain fall and temperature by Assosa Agricultural Research Center (ASARC), the similarities of climate conditions of experimental area with Assosa might be provided maximum seed yield than others. This finding is in line with Roy et al. (2009) who reported that the interaction effect of variety and row spacing was significant and as row spacing increases from $15 \mathrm{~cm}$ to $30 \mathrm{~cm}$, the yield also increases depending on varieties but decreases at the highest row spacing (low plant population). The authors concluded that variety BINA Til planted at $30 \mathrm{~cm}$ row spacing obtained highest yield of sesame than $45 \mathrm{~cm}$ row spacing. Other study by Gabisa et al. (2017) also found that interaction effect exists on variety and plant density in groundnut, the highest seed yield was recorded from variety Tole-1 sown at plant density of 250,000 plants/ha while the lowest seed yield was obtained from variety Fayo sown at lowest plant population $(142,857$ plants/ha). 
Table 3: Interaction effect of sesame varieties and plant population on seed yield $(\mathrm{kg} / \mathrm{ha})$ in optimum moisture areas of western Tigray during 2018 cropping season

\begin{tabular}{ccc}
\hline Variety & plant population (plants/ha) & Seed yield (kg/ha) \\
\hline \multirow{2}{*}{ Gida-Ayana } & 80,000 plants/ha $(20 \times 80 \mathrm{~cm})$ & $426.3^{\mathrm{de}}$ \\
& 124,444 plants/ha $(15 \mathrm{~cm} \times 60 \mathrm{~cm})$ & $568.5^{\mathrm{b}}$ \\
& 250,000 plants/ha $(10 \mathrm{~cm} \times 40 \mathrm{~cm})$ & $656.7^{\mathrm{a}}$ \\
& 666,666 plants/ha $(5 \mathrm{~cm} \times 20 \mathrm{~cm})$ & $583.7^{\mathrm{b}}$ \\
Humer-1 & 80,000 plants $/$ ha $(20 \times 80 \mathrm{~cm})$ & $413.7^{\mathrm{de}}$ \\
& 124,444 plants/ha $(15 \mathrm{~cm} \times 60 \mathrm{~cm})$ & $528.2^{\mathrm{bc}}$ \\
& 250,000 plants/ha $(10 \mathrm{~cm} \times 40 \mathrm{~cm})$ & $535.1^{\mathrm{bc}}$ \\
Hirhr & 666,666 plants/ha $(5 \mathrm{~cm} \times 20 \mathrm{~cm})$ & $485.9^{\mathrm{cd}}$ \\
& 80,000 plants/ha $(20 \times 80 \mathrm{~cm})$ & $383.7^{\mathrm{e}}$ \\
& 124,444 plants/ha $(15 \mathrm{~cm} \times 60 \mathrm{~cm})$ & $417.7^{\mathrm{de}}$ \\
LSD $(<5 \%)$ & 250,000 plants/ha $(10 \mathrm{~cm} \times 40 \mathrm{~cm})$ & $428.5^{\text {de }}$ \\
CV $(\%)$ & 666,666 plants/ha $(5 \mathrm{~cm} \times 20 \mathrm{~cm})$ & $392.3^{\mathrm{e}}$ \\
\hline
\end{tabular}

LSD: Least significance difference; CV (\%): Coefficient of variation; Means of the same letters are not significantly different at $5 \%$ level of significance.

\section{Conclusion and Recommendation}

The present research findings showed that the main effect of varieties and plant population were highly significantly differed in yield related traits. The variety Gida-Ayana recorded maximum fertile capsules per plant, thousand seed weight, seed per capsule and oil content (\%) while the local variety Hirhr recorded the least. Similarly, fertile capsules per plant, seed per capsule and thousand seed weight were highest in the low plant population than highest plant population but oil content (\%) was not affected by different levels of plant population. On the other hand, seed yield $(\mathrm{kg} / \mathrm{ha})$ were significantly influenced by the main effect of variety and plant population and their interaction effect. The maximum seed yield of $656.7 \mathrm{~kg} / \mathrm{ha}$ was obtained from variety Gida-Ayana with 250,000 plants $/ \mathrm{ha}(40 \mathrm{~cm} \times 10 \mathrm{~cm})$ which significantly increases yield by $34.75 \%$ as compared with local variety Hirhr with the same plant population. Hence, it can be concluded that higher seed yield and oil content (\%) of sesame could be obtained by using Gida-Ayana variety sowing at the plant population of 250,000 plants $/$ ha $(40 \mathrm{~cm} \times 10 \mathrm{~cm})$ under optimum moisture areas of western Tigray and similar agro-climatic conditions.

\section{Conflicts of Interest}

The author declares that there are no conflicts of interest regarding to publication of this paper.

\section{Acknowledgement}

I would like to thank Humera Agricultural Research Center and crop case team members for financial support and their assistance in the research work, respectively.

\section{References}

Abate S. (2003). Effects of irrigation frequency and plant population density on growth, yield components and yield of haricot bean (Phaseolus vulgaris L.) in Dire Dawa Area (Doctoral dissertation, M. Sc. Thesis Presented to Haramaya University, Ethiopia).

Abebe, N.T. (2016). Review of sesame value chain in Ethiopia. International Journal of African and Asian Studies. 19. pp. 36-47.

Ahmad, R., Mahmood, T., Farrukh, M.S. and Ahmad, S. (2002). Comparative performance of two sesame (Sesamum indicum L.) varieties under different row spacing. Asian Journal of Plant Science, 1(5), pp.546547.

Ali, M.H., M.J. Ullah, M.S.V. Bhuiyan and A.K.M.R. Amin. (1997). Effect of nitrogen and phosphorus on the yield attributes and yield of sesame (Sesamum indicum L). Bangladesh Journal of Agricultural Sciences, 24(1): 27-32.

Begum, R., Samad, M.A., Amin, M.R., Pandit, D.B. and Jahan, M.A. (2001). Effect of row spacing and population density on the growth and yield of sesame. Bangladesh Journal of Agricultural Sciences, 28(2), pp.311-316.

Caliskan, S., Arslan, M., Arioglu, H. and Isler, N. (2004). Effect of planting method and plant population on growth and yield of sesame (Sesamum indicum L.) in a Mediterranean type of environment. Asian J. Plant Sci, 3(5), pp.610-613.

Central Statistical Agency (CSA) of Ethiopia. (2019).Agricultural sample survey 2018/19 (2011 E.C.) report on 
area and production of major crops for private peasant holdings, Meher season, volume I. Addis Ababa. $\mathrm{http}: / / w w w . c s a . g o v . e t /$ survey-report/cate gory/373-eth-agss-2018.

Gabisa, M, Tana, T and Elias, U. (2017). Effect of planting density on yield components and yield of Groundnut (Arachis hypogaea L.) varieties at Abeya, Borena Zone Southern Ethiopia. International Journal of Scientific Engineering and Applied Science (IJSEAS), 3(3), pp.1-18.

Geremew, T., Adugna, W., Muez, B., Hagos, T. (2012). Sesame Production Manual. EIAR and Embassy of the Kingdom of the Netherlands, Ethiopia: pp. 1-34.

Govindarasu, R., Sivasubramanian, P. and Manian, K. (1998). Analysis of seed yield and yield components of sesame at coastal Karaikal. Journal of India Society of Agriculture, 7, pp.95-97.

Kale, R.A., Waghmare, P.K., Gokhale, D.N. and Bhalerao, G.A. (2018). Performance of sesame (Sesamum Indicum L.) varieties under different plant geometry during post monsoon season. Journal of Pharmacognosy and Phytochemistry, 7(5), pp.417-418.

Kathiresan G. (2002). Response of sesame (Sesamum indicum) genotypes to levels of nutrients and spacing under different seasons. Indian Journal of Agronomy, 47(4), pp.537-540.

Khan, M.H.A., Sultana, N.A., Islam, M.N. and Hasanuzzaman, M. (2009). Yield and yield contributing characters of sesame as affected by different management practices. American-Eurasian Journal of Scientific Research, 4(3), pp.195-197.

Lakew, S., Ayalew, D. and Assefa, F. (2018). Optimum inter-row spacing and seeding rate of sesame for harnessing the maximum productivity potential in the dry land area of Abergelle District, Northeast Ethiopia. Cogent Food \& Agriculture, 4(1), p.1485471.

Malik, M.A., Saleem, M.F., Cheema, M.A. and Ahmed, S.H.A.M.I.M. (2003). Influence of different nitrogen levels on productivity of sesame (Sesamum indicum L.) under varying planting patterns. Int. J. Agri. Biol, 5(4), pp.490-492.

Mohammed, B. and Hamidu, G.A. (2018). Growth and Yield Performance of Sesame (Sesamum indicum L.) Varieties at Varying Levels of Inter-row Spacing in Northern Part of Sokoto, Nigeria. Asian Journal of Research in Crop Science, pp.1-14.

Rahnama, A. and Bakhshandeh, A. (2006). Determination of optimum row-spacing and plant density for unibranched sesame in Khuzestan province.

Roy, N., Abdullah, S.M. and Jahan, M.S. (2009). Yield performance of sesame (Sesamum indicum L.) varieties at varying levels of row spacing. Research Journal of Agriculture and Biological Sciences, 5(5), pp.823827.

Sivagamy, K. and Rammohan, J. (2013). Effect of sowing date and crop spacing on growth, yield attributes and quality of sesame. IOSR Journal of Agriculture and Veterinary Science 5 (2): $38,40$.

Taghouti, M., Nsarellah, N., Gaboun, F. and Rochdi, A. (2017). Multi-environment assessment of the impact of genetic improvement on agronomic performance and on grain quality traits in Moroccan durum wheat varieties of 1949 to 2017. Global journal of plant breeding and. Genetics, 4, pp.394-404.

Umar, H.S., Okoye, C.U. and Mamman, B.D. (2010). Resource use efficiency in sesame (Sesamum indicum L.) production under organic and inorganic fertilizers applications in Keana Local Government Area, Nasarawa State, Nigeria. Research Journal of Agriculture and Biological Sciences, 6(4), pp.466-471.

Valiki, S.R.H., Ghanbari, S., Golmohammadzadeh, S. and Kiasari, K.R. (2015). Effect of different plant density on growth and yield of three cultivars of sesame (Sesamum indicum L.). In Biol Forum Int J. 7, pp. 15241528.

Wijnands, J.H.M., Biersteker, J. and Van Loo, E.N. (2009). Oilseeds business opportunities in Ethiopia November 2009, The Hague, Netherlands. pp.1-62. 